University of Louisville

ThinkIR: The University of Louisville's Institutional Repository

\title{
"Divest now!" The student divestment campaign at the University of Louisville : a crusade for equality.
}

Chris Burns

Follow this and additional works at: https://ir.library.louisville.edu/honors

Part of the History Commons, Race and Ethnicity Commons, and the Race, Ethnicity and Post-Colonial Studies Commons

\section{Recommended Citation}

Burns, Chris, "'Divest now!" The student divestment campaign at the University of Louisville : a crusade for equality." (2016). College of Arts \& Sciences Senior Honors Theses. Paper 112.

http://doi.org/10.18297/honors/112

This Senior Honors Thesis is brought to you for free and open access by the College of Arts \& Sciences at ThinkIR: The University of Louisville's Institutional Repository. It has been accepted for inclusion in College of Arts \& Sciences Senior Honors Theses by an authorized administrator of ThinkIR: The University of Louisville's Institutional Repository. This title appears here courtesy of the author, who has retained all other copyrights. For more information, please contact thinkir@louisville.edu. 


\section{“Divest Now!”}

The Student Divestment Campaign at the University of Louisville: A Crusade for Equality

By:

\section{Chris Burns}

Submitted in partial fulfillment of the requirements for Graduation magna cum laude

and

Graduation with Honors from the Department of History

University of Louisville

March 2016 
In the 1980s, university students across the United States of America embarked on a nationwide crusade against apartheid. They saw the efforts of South Africans who stood up against the injustices of apartheid and witnessed the violence and terror employed by the government against its own citizens. These American students responded with vigor by holding demonstrations, signing resolutions, and occupying administration buildings in an effort to coerce their respective institutions to divest holdings in or with the South African government. These students knew there was little they could do to end apartheid, but they also realized that the South African economy needed American investment in order to function. By pressuring administrations to divest, these student-activists challenged apartheid where they could and thus localized a global struggle. The student-led divestment campaign was a major part of the American anti-apartheid movement and directly influenced the economic sanctions that later crippled the apartheid state. The movement was truly a national one. Divestment movements occurred on campuses from Rutgers University in New Jersey to the University of CaliforniaLos Angeles.

The University of Louisville experienced its own student-led divestment movement in the spring of 1985, and in the process carved out a unique niche in the narrative of the university divestment campaign. When calls for divestment went unheeded by University of Louisville administration and the Board of Trustees, members of student-led anti-apartheid organizations held an overnight sit-in at the university Information Center on April 23, 1985. Although it was not until October 1985 when the University of Louisville administration and its board of trustees formally decided to divest all university funds from South Africa, the student-led divestment campaign was a driving force in that decision. The 1985 divestment campaign at the University of Louisville provides historians with a fascinating case study within the university divestment 
movement, the anti-apartheid movement nationwide, and the international struggle to bring an end to apartheid in South Africa.

The divestment campaign at the University of Louisville stands out for a variety of reasons. While most historical recollections of the university divestment campaign tend to focus on instances of civil disobedience at more esteemed, private institutions such as Columbia University, the University of Cal-Berkeley, and Harvard University, the divestment campaign at the University of Louisville proved to be one of the first public institutions outside of these wellknown universities to fully divest. ${ }^{1}$ The University of Louisville was the first Southern institution to pursue full divestment and the first university in Kentucky to divest as well. The University of Louisville has had a long tradition of student activism, yet the 1985 divestment campaign proved to be one of the final times that Louisville students successfully demonstrated en masse against an administration policy. Finally, the divestment campaign at Louisville provides students with an historical precedent of peaceful activism and an example of just how impactful student-led movements can be. This thesis outlines not only the narrative of divestment at Louisville, but also the history of apartheid in South Africa, the international context of the time, and the overall divestment effort in the United States in 1985. By doing this, the intended goal is not only to tell the story of the divestment movement at Louisville but to show that the campaign maintains a truly unique place in the global fight against apartheid. It also articulates the university’s role within this global struggle, which has been overshadowed by the demonstrations at more elitist schools (i.e. Harvard, Columbia and the University of California-Berkeley). Given the fact that this movement came from a public school with a largely commuter student body in the South remains unique and important. 


\section{Life Under Apartheid}

Apartheid was a systematic oppression of an entire population, a method by which the white minority attempted to render people of color completely powerless. It shaped everyday norms, such as where your child went to school, where your family was allowed to live, and where you were allowed to work. As the Nationalist Party (NP) codified and extended racial discrimination over the twentieth century, ${ }^{2}$ a distinct social order developed with white South Africans on top, then Indians, blacks, and mixed peoples (Coloureds) well below them. How did this come to be a fundamental aspect of South African society? In order to understand underlying causes of apartheid, its origins must be explored and analyzed.

While the racial divisions that defined apartheid took root in South Africa as far back as the arrival of Europeans to the Cape of Good Hope during the $15^{\text {th }}$ century, 1948 was the year when the "legislative discrimination" of apartheid began. ${ }^{3}$ The fundamental idea behind apartheid was the separation of South Africans by race (the term itself is essentially Afrikaans for “apartness”), and Prime Minister D.F. Malan, head of the white Afrikaner Nationalist Party, moved quickly to ensure the “compartmentalization” of South Africa’s population. ${ }^{4}$ The government passed legislation barring interracial marriages and the movement of certain races to particular areas of the country. Africans were required to carry passes that stated both their race and the areas in which they were permitted to be, with serious punishments befalling those who either did not show their pass or disobeyed the restrictions set upon them. The Group Areas Act (1950) separated residential areas by race, and the Reservation of Separate Amenities Act of 1953 enforced social segregation in all areas of public life from transportation to sports events, restaurants and cinemas. ${ }^{5}$ 
The governing arm of apartheid stretched into education and employment as well. In 1953, the South African legislature passed the Bantu Education Act. This statute brought all African schools under the control of the Department of Native Affairs, an institution that was created by the apartheid state as a means to govern and control the African population.

According to Nelson Mandela, “either the government took over education for Africans, or there would be no education for Africans.”6 The Bantu Education Act imposed a uniform curriculum that stressed a distinct "Bantu culture," all the while deliberately preparing African students for little more than a life of manual labor. ${ }^{7}$ In 1956, amendments made to the Mines and Work Act (originally passed in 1911) insured that whites were given access to higher-paying jobs, while Africans and other "non-Europeans” were restricted to taking jobs in positions of manual labor. The rules and regulations of apartheid extended to virtually every area of life. By the mid-1950s, apartheid had created a society where whites were the only ones with true rights.

African, Indian, and Coloured populations, however, were not merely passive actors in this era of subjugation. Anti-apartheid activism began from the NP's rise to power in 1948, highlighted by rise of the African National Congress (ANC). The ANC had formed in 1912 following the establishment of the Union of South Africa in order to protect the interests of black South Africans. However, the ANC was not a populist movement for much of its history; it functioned as an organization of land-owning intellectuals petitioning for the rights of Africans until the mid-1950s. Under the leadership of Nelson Mandela, Chief Albert Luthuli, Walter Sisulu, Oliver Tambo and others, however, the ANC came to mobilize the masses. The group’s fight against apartheid began in 1952 with the Defiance Campaign. On June 26, scores of brave men and women challenged the South African government by refusing to attend work. Over the next five months, thousands of doctors, factory workers, lawyers, teachers, students, and 
religious leaders took part in the campaign, leading to the arrests of approximately 8,500 people. ${ }^{8}$ Despite the crackdown by the apartheid state, membership in the ANC increased dramatically, reaching 100,000 by $1953 .{ }^{9}$ The ANC worked closely with organizations like the Natal Indian Congress (NIC), the South African Coloured People’s Organization (SACPO), and the largely white South African Communist Party showing that different racial groups “could work together" to overcome apartheid. ${ }^{10}$ The ANC and its allies provided hope to millions of South Africans that they could be "liberated... from the feeling of being overwhelmed by the power and seeming invincibility of the white man and his institutions."11

Despite the sustained resistance of the ANC and other anti-apartheid organizations, the South African government maintained overwhelming control over its domestic affairs. The state became increasingly intolerant of any form of civil disobedience, and began using more brutal and violent means to suppress dissent. Legal statutes such as the 1951 Suppression of Communists Act gave the government the power to ban any person or organization they considered to be "communist," an incredibly broad definition that came to include anyone who openly opposed apartheid. ${ }^{12}$ In 1956, the South African police arrested 156 activists on suspicion of inciting a Communist revolution, a charge that would be denounced in court after a long and protracted legal battle. ${ }^{13}$ The government was able and incredibly willing to use its authority to levy charges, bans, and sentences against anti-apartheid activists. However, these were by far the tamest forms of suppression utilized by the apartheid state. The South African government routinely responded to civil disobedience with much harsher and violent methods.

In March of 1960, South African police opened fire on a group of demonstrators in the township of Sharpeville, killing sixty-nine people, many of whom were shot in the back as they fled. ${ }^{14}$ The massacre marked a dramatic turning point in South African history as anti-apartheid 
activists realized that much more drastic action was needed to combat the cruelty of the South African government. ${ }^{15}$ As Mandela stated solemnly in Long Walk to Freedom, "At a certain point, one can only fight fire with fire."16 More riots and demonstrations erupted across the country. On March $28^{\text {th }}$, another massive ANC-led day of defiance resulted in thousands abstaining from work, while at the same time protests in Cape Town drew crowds of up to $50,000 .{ }^{17}$ International outcry regarding Sharpeville increased as well. The United Nations Security Council condemned the Union of South Africa for its role in the "large-scale killings of unarmed and peaceful demonstrators" while also underlining the need for "racial harmony" in South Africa. ${ }^{18}$ Fearing the outbreak of a black revolution, many South African whites made plans to emigrate. ${ }^{19}$ It seemed as though real change was forthcoming for millions of oppressed South Africans.

Nevertheless, South Africa's freedom fighters learned the hard way that "it is the oppressor who defines the nature of the struggle.” ${ }^{20}$ The South African government responded with a definitively swift and brutal punishment. In 1964, Mandela, Sisulu, and nearly the entire ANC executive leadership were tried and sentenced to life imprisonment in the "iron-fisted" Robben Island prison. ${ }^{21}$ Others like Oliver Tambo, fled into exile. With much of the leadership in prison or exile, the anti-apartheid movement faced major difficulties. In South Africa, a period of "relative calm" ensued despite the continued implementation of apartheid rule. ${ }^{22}$ International attention shifted from the atrocities of Sharpeville to other issues like the Cold War, the Cuban Missile Crisis, the Space Race, the Vietnam War, and the sweep of Independence elsewhere on the African continent. Unfortunately, it would take a tragedy of monumental proportions for citizens around the world to finally stand up and demand change in South Africa. 
On June $16^{\text {th }}, 1976$, nearly twelve thousand primary-and secondary-school students in the black township of Soweto boycotted classes and marched in opposition to the state's policy that all lessons (particularly Math and Science) must be taught in Afrikaans. For many Africans, Afrikaans was considered the language of their oppressors, the Afrikaner minority. They resented this new policy, as they believed it limited their educations and later job prospects. As these young students marched through the township, South African police opened fire, resulting in nearly seventy dead and more than four hundred wounded. ${ }^{23}$ Protests turned into full-scale riots over the following weeks. By the end of 1976, an estimated 575 people had been killed and over 2,000 more wounded. ${ }^{24}$ The international community was horrified. Anti-apartheid organizations around the world called for cultural, economic, and political sanctions against South Africa. The willingness of the police to use deadly force to silence even nonviolent dissent indicated the ominous direction in which white South African society was moving, and gave the world a true glimpse of the cruelty and oppression of the apartheid regime. ${ }^{25}$ In spite of the carnage the Soweto uprisings incurred, they provided the necessary spark of global outrage that would help drive the engine of change in South Africa. With the June 16th Uprisings and the violence that followed, the world witnessed the savagery of apartheid in their newspapers and on their televisions. Like the Sharpeville Massacre had galvanized anti-apartheid activism across the world, a new generation now witnessed the wickedness of apartheid. This shift would have major implications in American activist circles. 


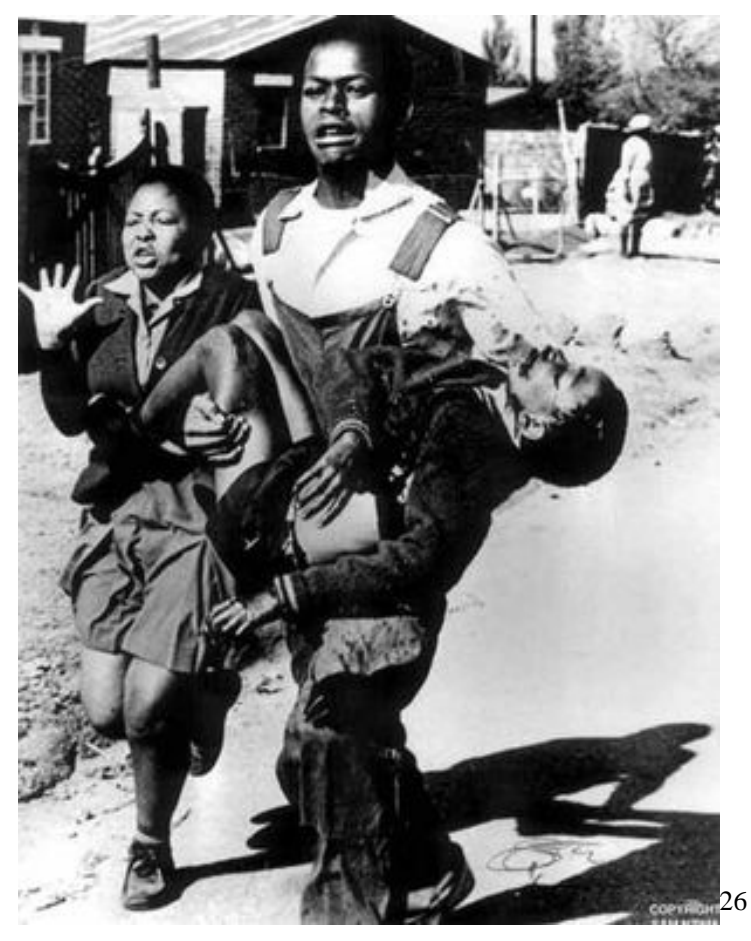

The body of Hector Pieterson, a young student slain during the Soweto Uprisings, is carried by a fellow student and his sister. The tragedy of this image shocked the world, and provided anti-apartheid activists with visual proof of the brutal nature of apartheid in South Africa.

\section{America and Apartheid}

In 1976, Georgia Senator Jimmy Carter defeated the incumbent for the office of President of the United States. Carter's victory implied a change in direction for United States foreign policy, one that potentially could be geared towards openness, morality, and a steadfast commitment to the protection human rights. ${ }^{27}$ For the Carter Administration, there was no more ideal arena to demonstrate this conviction than Africa. ${ }^{28}$ While American foreign policy in the mid-20 $0^{\text {th }}$ century was defined by the nuclear tensions of the Cold War, the Carter Administration devoted more attention to improving relations with African nations than had any of its predecessors. ${ }^{29}$ Carter was the first sitting president to visit the African continent when he travelled to Nigeria in 1978, showing his dedication to fostering strong diplomatic and economic ties with African nations. ${ }^{30}$ Carter also strengthened his relationship with African nations by 
appointing Andrew Young, a black Civil Rights activist and Congressman from Georgia, as the US ambassador to the United Nations. Young became a "vociferous and uninhibited" spokesman that drew acclaim among African leaders for his support of majority rule on the continent, and, in particular, his steadfast condemnation of apartheid. ${ }^{31}$

The Carter Administration’s battle against apartheid reached its peak very early in President Carter's tenure. In 1977, the United States, along with the United Nations, imposed a military arms embargo that cut off the export of police and military equipment from the United States to South Africa, and also barred South African military officials from visiting the United States. That same year the "Sullivan Principles," developed by General Motors board member and civil rights activist Reverend Leon Sullivan, set about applying certain economic restrictions on American corporations conducting business with South African companies. Corporations dealing internationally were required by the Sullivan Principles to support "universal human rights," particularly those of the employees, the communities within which they conducted business, and the parties involved in transactions. ${ }^{32}$ The "Sullivan Principles," as they came to be known, became a standard by which hundreds of investors across the United States judged corporate behavior. The development of the Sullivan Principles represented a new precedent for business and investors who wished to do businesses with South Africa: no longer could human rights' violations be outright ignored when conducting business overseas. The actions of the Carter Administration combined with the implementation of the Sullivan Principles exemplified a willingness to use American influence to promote equality and discourage racist legislation in South Africa.

However, the Carter Administration overall was unwilling to "go beyond symbolic disassociations with apartheid, refusing to use economic sanctions as a means of pressuring the 
South African government into reform.”33 The primary reason for this hesitancy was the prevalence of Cold War tensions. Attention to human rights waned relative to the renewed concern with traditional security issues, exemplified by the Iranian hostage crisis and the Soviet invasion of Afghanistan in 1979. By the end of the Carter Administration, American foreign policy in Africa had shifted from the pursuit of racial justice and majority rule to the ongoing, and seemingly never-ending, philosophical war with the Soviet Union. ${ }^{34}$ Though it had at first hinted at ending of American tolerance of apartheid, the Carter Administration did not take the necessary steps to truly challenge the perverse inequalities and injustice linked to apartheid. With Carter's defeat to Ronald Reagan in 1980, the hopes of America further challenging apartheid appeared dashed.

The Reagan Administration took an even more lenient stance towards apartheid, a move that would draw the ire of anti-apartheid activists. Reagan's support for South Africa became readily apparent early in his presidency. In his campaign, Reagan had denounced Carter's position against apartheid, claiming that “South Africans certainly don’t need us to tell them how to solve their race problems.”35 Upon taking office, Reagan offered “conciliatory gestures” towards the apartheid regime, even bringing South African foreign minister Pik Botha to the White House in May 1981 despite the United Nations' embargo with the country. ${ }^{36}$ The meeting prompted the adoption of Reagan’s “constructive engagement” policy. "Constructive engagement” rested on three important assumptions: the whites of South Africa were there to stay, the whites were staunch anticommunist allies to the United States (and thus needed by the US to fight the Cold War), and South Africa was a welcome member of Western civilization. ${ }^{37}$ Constructive engagement indicated to anti-apartheid activists that the Reagan Administration was willing not only to accept apartheid but willing to recognize the regime as a legitimate ally. 
Reagan's approach to apartheid infuriated anti-apartheid activists, and provided the spark for the explosion of the anti-apartheid and divestment campaigns that swept the country in President Reagan's second term.

With the executive branch and half of the legislature firmly secured by conservatives, hopes for federal action on South Africa had all but disappeared by the mid-1980s. Antiapartheid activists recognized that new efforts and greater cooperation were needed if the system of apartheid was ever to be abolished. Reagan’s blatant support for apartheid became a major catalyst for a surge of grassroots anti-apartheid activism and the formation of major antiapartheid political coalitions. Leaders like Randall Robinson, a noted African American lawyer, author, and civil rights activist, realized that drastic actions were needed in order to rouse domestic resistance to apartheid and upend Reagan’s “constructive engagement” policy. Robinson and other leaders were essential in spreading support for the anti-apartheid movement through the African American community, religious groups, trade unions, and eventually college students across the country.

After Reagan’s reelection in November 1984, Robinson recalled hearing of South African whites “dancing in the streets” of Johannesburg after the election, invigorated by the notion that they were "safe for four more years." ${ }^{\text {38 }}$ In response, on November 21, Robinson and three other dissidents entered the South African embassy in Washington, D.C. Once inside, they demanded the release of hundreds of political prisoners in South Africa and refused to leave until their demands were met. Their actions helped launch a “new national campaign” against apartheid. ${ }^{39}$ In the following days, Robinson announced the creation of The Free South Africa Movement (FSAM). Formed with the intention of appealing to the consciences of grassroots activists, FSAM was a direct response in opposition to the Reagan Administration's policy of 
“constructive engagement." 40 The Free South Africa Movement (FSAM) became the "catalyst for the resurgence in anti-apartheid activism," ${ }^{41}$ giving new life to the anti-apartheid movement in the United States.

The primary goal of the FSAM was to galvanize Americans into greater action and stretch out demonstrations for as long as possible. "We are in it for the long haul,” Robinson told the New York Times in late November 1984, “we have enough willing people... to let us continue these protests indefinitely.”42 FSAM soon gained additional support from union leaders, members of Congress, and notable activists like Harry Belafonte, Coretta Scott King, and Reverend Jesse Jackson. ${ }^{43}$ However, Robinson, Jackson, and other activists knew that the campaign to end apartheid would fail without sustained activism at local levels. They then looked to the generation behind them, to students at American universities. When Rev. Jackson penned a letter to the administration at Harvard University in March of 1985, he did so with the hope of fueling a student-led anti-apartheid movement. However, even he did not anticipate the incredible outpouring of activism by American college students in the oncoming months.

\section{College Divestment and Apartheid}

Divestment, simply put, is the opposite of investment. Investment involves using one’s own funds to buy into a certain asset such as stock in a certain company or commodity. Divestment, on the other hand, involves taking one's funds out of a particular company or commodity. Anti-apartheid activists argued that that American investment played a significant role in maintaining apartheid in South Africa. Activists referenced companies such as IBM, who supplied the apartheid government with computers used to track the movements of black South Africans, and Ford, who provided South African police forces with cars and trucks used to round 
up and detain black South Africans as just two examples of American corporations that directly profited from the repression of non-whites in South Africa. ${ }^{44}$ Withdrawing American investment from South Africa was the first and most important step to signifying to the apartheid regime that its gross violations of human rights were intolerable. Without monetary support from the United States, the apartheid government would be unable to maintain its oppressive hold on the nonwhite majority of South Africa. Divestment could then be used as an important vehicle for promoting equality and societal change.

The college divestment movement began in earnest in 1985. Students were alarmed by the inequality and brutality of apartheid. Many felt that they, as well as their respective universities, were responsible for having stood idly by while millions of South Africans suffered under apartheid. This feeling of moral culpability was only exacerbated when in 1980 the South African government dispatched the army to occupy black townships as a measure to quell riots and protests. Black South Africans responded to this with widespread resistance. By the mid1980s, virtual civil war existed in many parts of the country. ${ }^{45}$ The increased violence fostered a “sense of urgency" amongst student activists, spurring them into action. ${ }^{46}$

The divestment campaign spread across the United States onto the campuses of public and private universities alike, including the University of Wisconsin-Madison, the University of California at Los Angeles, Rutgers University, and Oberlin College. ${ }^{47}$ Perhaps the most significant divestment effort came on the campus of one of America's most prestigious and wellknown institutions: Columbia University. In April 1985, Columbia became the epicenter of the student divestment movement when seven members of the student-led Coalition for a Free South Africa (CFSA) staged a hunger strike due to their dissatisfaction with the Columbia Board of Trustees’ noncommittal policy towards divestment. Despite their efforts, the students were 
rebuffed by the university's administration, and even mocked by one trustee who reportedly said "Let them go ahead and fast." 48

Undeterred, Columbia students continued demanding divestment. On April 4, eleven days into their hunger strike, the Coalition for a Free South Africa called for a "National Divestment Protest Day” with a rally to be held on the steps of Hamilton Hall. ${ }^{49}$ There, student leaders, esteemed alumni, and a slew of political speakers took turns addressing the crowd of over five-hundred that had gathered to support the campaign. ${ }^{50}$ The CFSA iterated that studentled protests and demonstrations had been an effective way of forcing a "concrete response" from university officials. ${ }^{51}$ The next course of action, they argued, was to occupy Hamilton Hall until "the university divested or arrested them" ${ }^{52}$ They were shocked when, upon entering, over a hundred fifty students had joined the sit-in. ${ }^{53}$ The doors were chained and the message was sent to Columbia's trustees: we leave when you comply, or when you force us out.

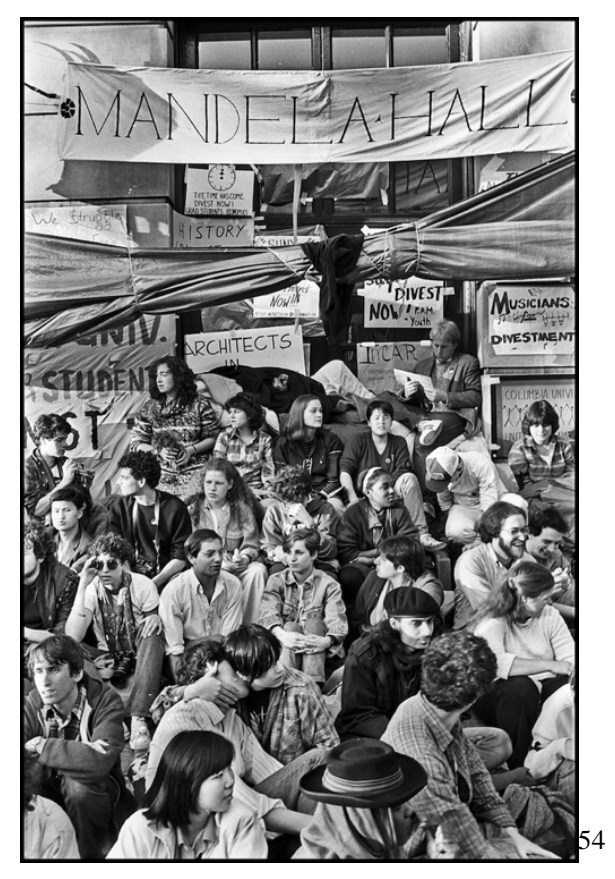

Students at Columbia University set up banners during their occupation of Hamilton Hall. They renamed the building after Nelson Mandela, South Africa's leading black activist.

Within hours of the its occupation, Hamilton Hall was transformed by the student activists into "Mandela Hall," complete with banners and flags commemorating the South 
African activist who had been incarcerated by the apartheid state. Students were organized into specific groups responsible for obtaining food, sleeping bags, and rain gear. ${ }^{55}$ A small group contacted reporters in order to spread the word about the movement. A daily newsletter, The Divestment Blockade, was created to pass information to reporters and appeal to supporters. ${ }^{56}$ The demonstration was a well-organized, coherent, and determined effort. One activist, Jose Ribera deSousa, declared that divestment was not something to be debated- it was a matter of “life or death."57 The students' dedication was to be tested in the coming weeks, as administrators debated the best way to handle the protest occurring at the heart of their university.

A week later, students awoke inside the hall to find a letter written to them by President Sovern threatening students with expulsion or suspension if the sit-in continued. The President's warning only further galvanized the students who relished in the idea that their protest had generated such a reaction from a president who had previously refused to recognize their grievances. ${ }^{58}$ Celebrities and South African activists like Bishop Desmond Tutu sent support to the blockade, providing even more motivation for the students to continue their protest well into April. ${ }^{59}$ On April 22, over two weeks into the blockade, New York state officials demanded that students remove the chains from the doors. Three days later, the students finally cut the chains and marching out of Mandela Hall directly to a rally at the Canaan Baptist Church in Harlem, where Wyatt T. Walker, a confidant of the late Dr. Martin Luther King, welcomed the students as “companions in the global battle for racial justice."60 The students had gained nationwide and even international recognition for their dedication to fighting the injustices of apartheid, putting the student divestment movement onto a global stage. 
The efforts of students at Columbia were replicated throughout the United States. The Coalition for a Free South Africa called for similar protests on "National Divestment Protest Day”; hundreds upon hundreds of students demanded divestment on the campuses of institutions like Harvard University, Stanford University, Amherst College, and Princeton University. ${ }^{61}$ The divestment campaign began to make national headlines, and inspired anti-apartheid leaders to capitalize on the newfound momentum. ${ }^{62}$ Reverend Jackson himself made stops at Harvard, Rutgers University, and Princeton, calling the divestment campaign the "highest calling of our day.”63 Anti-apartheid leaders had spurred college students into action, and they had responded with gusto. Soon the divestment campaign spread from more elitist, private colleges and universities, to public institutions around the nation. One such institution, the University of Louisville, became the first, and only, public Southern university to divest from companies doing business with or in South Africa, displaying just how far the divestment campaign reached in the spring of 1985.

\section{The University of Louisville Divestment Campaign}

In January 1985, members of the University of Louisville’s Progressive Students League (PSL) met and decided to make the issue of apartheid an emphasis during the upcoming spring semester. Though the exact reasons for this decision remain unclear, this meeting marked the official beginning of the University of Louisville divestment campaign. Their first act of civil disobedience occurred on February 19 when members of the PSL picketed representatives of Firestone Tire \& Rubber Co. due to the company’s alleged “corporate support” of apartheid. ${ }^{64}$ That same day, the University of Louisville Student Senate, led by Student Government Association (SGA) President Frank Jemley III and Senate Chairman Douglas Kemper, drafted 
and passed an official “Divestment Resolution.” The Divestment Resolution demanded that the University of Louisville Foundation, an independent organization tasked with handling the university’s investments, withdraw all “funds, assets, or other holdings... in any bank or financial institution” dealing in or with apartheid South Africa no later than April 1 1986. The resolution also called on all other institutions of higher learning in Kentucky and across the United States to “undertake similar acts of divestiture of South Africa-related assets”, and resolved to ultimately find an end to apartheid in South Africa. ${ }^{65}$ Although Jemley and Kemper were not directly involved in the PSL, the construction of the Divestment Resolution exemplified how the University of Louisville student body rallied behind the PSL and their mission to compel the university to divest. The Divestment Resolution became the foundation of the divestment campaign at the University of Louisville, and triggered a clash between students and university administrators that spanned most of 1985.

Over the next month, students from the PSL and its affiliate group, the Students Against Apartheid (SAA), coordinated to spread anti-apartheid awareness amongst the student body at Louisville. On February 28, the SAA sponsored a lecture by Naomi Tutu, the daughter of Bishop Desmond Tutu who happened to be a masters student at the nearby University of Kentucky, to discuss apartheid and its abhorrent consequences on black South Africans. ${ }^{66}$ Just over a week later, the SAA started a petition drive around campus on March 8, calling on fellow students to support a policy of complete divestment. ${ }^{67}$ Five days later, the University of Louisville Faculty Senate expressed its solidarity with the divestment campaign by voting on and passing the Divestment Resolution. ${ }^{68}$ These actions drew the attention of the University of Louisville Board of Trustees and President Donald C. Swain. On March 25, the university’s Board of Trustees, headed by Chairman Gene Gardner, met with representatives of the SAA to 
discuss the Student Senate’s Divestment Resolution and the possibility of pursuing divestiture from South Africa. The SAA finally were granted the opportunity to confront university leaders over the issue of divestment.

The SAA soon came to find out, however, that full divestment would not be easily achieved. The representatives demanded the board endorse and adopt the Divestment Resolution and divest all university funds from South Africa. ${ }^{69}$ Jemley requested that President Swain also write a letter to President Reagan urging him to seek strong opposition to apartheid. ${ }^{70}$ Though Swain acknowledged that he and his fellow board members agreed that apartheid was “reprehensible,” he was reluctant to accept that divestment was the answer to ending apartheid, stating that he and other board members disagreed on the "specific steps to be taken to bring the end of apartheid." ${ }^{71}$ Swain then recommended to his fellow trustees that the University of Louisville Foundation be tasked with reviewing the Divestment Resolution and deciding the “appropriate action” to take in the near future. ${ }^{72}$

The floor was then turned over to Jemley and other SAA representatives. Each student made a separate case for divestment, presenting a wide range of facts, statistics, and emotional pleas. Students directed accusations at President Swain and the board, alleging that the administration was too worried about their "corporate stocks” and had let money control their decision. ${ }^{73}$ American corporate investment was "vital to the operation of the racist regime in South Africa,” argued SAA representative Janet Zakutansky, and the University of Louisville was profiting from the "gross violations of human rights" that occurred in South Africa under apartheid. ${ }^{74}$ Tempers flared at various points in the discussion; Chairman Gardner threatened to kick the SAA representatives out of the meeting on multiple occasions. Jemley concluded the students’ arguments for divestment stating that full divestment was the "last chance” for the 
University of Louisville to uphold its “ethical and legal responsibilities” as an institution dedicated to higher learning. "Pressure from the free world,” Jemley asserted, was the only way to "abate the spiraling cycle of violence” in South Africa under apartheid, and that it was up to institutions like the University of Louisville to lead the way in promoting equality, justice, and acceptance. $^{75}$

After each student had made his or her case to the members of the board, discussion of the Divestment Resolution was turned over to the Board of Trustees for deliberation and a vote. Two trustees, Mr. Norbert Blume and Mr. Woodford Porter, openly voiced support for the resolution. While Blume did not cite a specific reason for supporting the resolution, Porter argued that divestment from South Africa presented the University of Louisville with an opportunity to be among the world's leaders in a "movement for human rights and human dignity."76 Porter cited his experiences as a black man whose family had once been slaves, and called on his fellow trustees to think with their consciences. "I ask you to let your decency come out on top," Porter stated, "if this little drop in the ocean will help bring that end (to apartheid), I ask (the Board of Trustees) to help bring it."77

Nonetheless, the majority of the board endorsed President Swain's motion to have the University of Louisville Foundation examine the possibility of divestment policies. Even Blume, who as previously mentioned had openly stated his support for divestment, agreed with President Swain's motion to have the University of Louisville Foundation examine the possibility of divestment. ${ }^{78}$ Ultimately, the student Divestment Resolution was struck down by a final vote of 11 against to 5 in favor. Upon hearing the result of the vote, students then began chanting in protest as the trustees' meeting recessed. ${ }^{79}$ Despite the denial of their resolution, the SAA and its members refused to renege on their commitment to achieving full divestment and the eventual 
end of apartheid in South Africa.

The PSL and SAA remained relatively quiet over the next few weeks. Their inactivity was not because students felt defeated or in any way discouraged by the board's decision. On the contrary, student anti-apartheid activists were in the midst of planning a larger demonstration that they felt would force President Swain and the Board of Trustees to seriously consider divestment. Much like Reagan’s policy of “constructive engagement” invigorated the national anti-apartheid movement, the decision by the university Board of Trustees to support President Swain's plan spurred students to take greater action against the university’s financial policy regarding apartheid South Africa. The divestment campaign at the University of Louisville soon reached its climax.

On the afternoon of April 23, 1985, a group of about 25 students and faculty members marched across campus from the student cafeteria to the administration building where President Swain and members of the University of Louisville Foundation were meeting in private. As they went, the protestors chanted “President Swain you can’t hide! We know you're on apartheid’s side!"80 The marchers then entered the university’s administration building and demanded to speak with President Swain and the Foundation’s members. Campus police arrived soon thereafter and rebuffed the protestors by promptly kicking them out of the building. ${ }^{81}$ 
Auguste Rodin's famous statue “The Thinker" has its hands full with a sign calling for divestment. This was a strong message to university administrators who were meeting in the building immediately behind the statue.

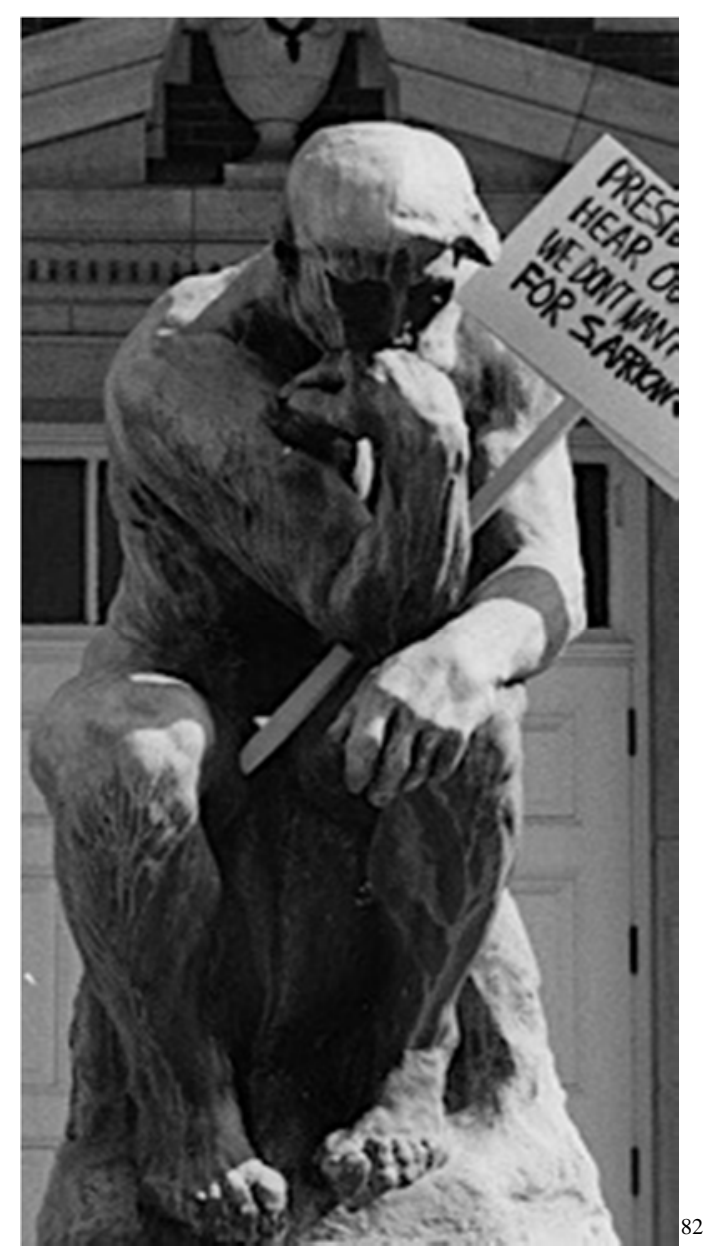

Not to be deterred, the protestors, who had given themselves the new name of the Coalition for Total Divestment (CTD), decided to peacefully occupy the university information center immediately southwest to the administration building on the university's main circle. They renamed the information center and circle drive the "Steve Biko Center" and "Divestment Lane,” respectively. ${ }^{83}$ They also affixed a hand-painted "Free South Africa” banner to the doors of the occupied building. At the same time as protestors gathered on the sidewalk, members of the Air Force ROTC conducted a parade drill on the grass behind the information center. The martial music and rigid marching of the ROTC clashed with the dancing, singing, and chanting of the demonstrators. ${ }^{84}$ The throng of protestors swelled as the day went on, with around 60 students and faculty members joined together all calling for one thing: divestment. ${ }^{85}$ 
Around 35 students stayed overnight in the tiny booth, agreeing to vacate the building the following day. By the afternoon of April 24, Swain and members of the University of Louisville Foundation voted unanimously to partially divest funds from firms doing business that did not adhere to the Sullivan Principles. In all, the Foundation voted to divest between \$1-2 million of the estimated \$9.2 million worth of stock the university had invested in South Africa-related firms at that time. President Swain heralded the decision by the Foundation as a "forthright stance in opposition to apartheid” and hoped that the decision was sufficient in both signifying their opposition to apartheid and appeasing student activists who had called for full divestment. ${ }^{86}$

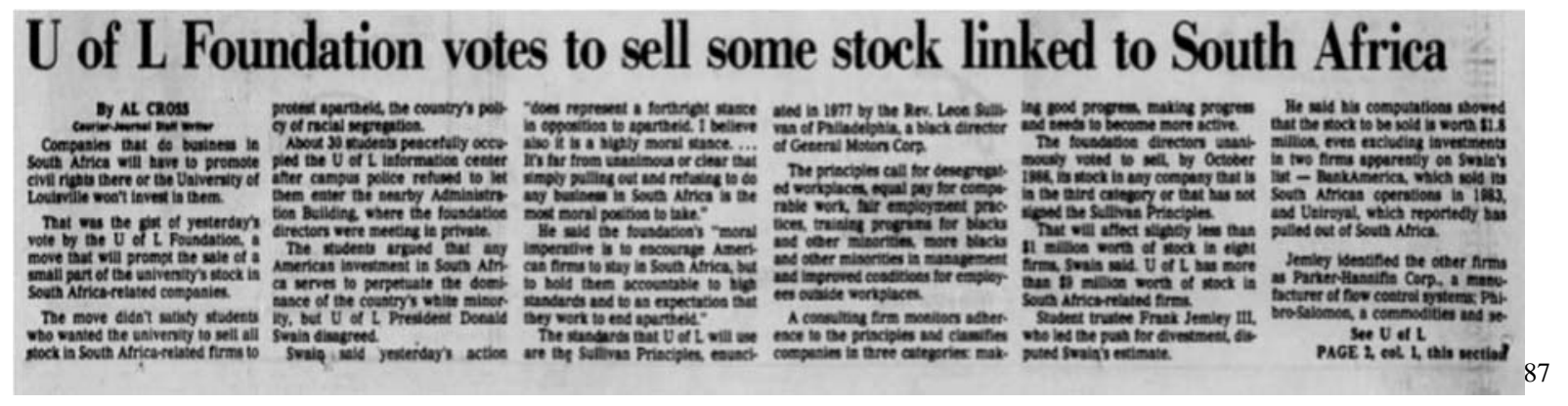

Headlines from April 241985 of the Courier-Journal. Despite the promise to partially divest from South Africa, student activists were not satisfied with the decision by University of Louisville administration.

Leaders of the Coalition for Total Divestment were not satiated by the Foundation’s decision. They called the measures “totally unacceptable” and “inadequate.” They argued that partial divestment was a "good first step" only if full divestment was to follow. ${ }^{88}$ They noted that the Sullivan Principles merely established a system of ethical criteria that businesses dealing in or with the government of South Africa were required to follow, and that these principles did not actually “condemn... nor call for an end to apartheid.”89 To the CTD, an investment plan based 
on the standards of the Sullivan Principles was not sufficient to actually meet their demands. ${ }^{90}$ As a result, the CTD remained staunch in their support of the original Divestment Resolution that had been passed by the Student Senate earlier that year, and they maintained their position that apartheid should be fought by any means.

The divestment campaign continued through the summer of 1985 and into the fall semester at the University of Louisville. Members of the CTD met in late August to discuss the possibility of staging another sit-in or demonstration. In September, the Student Senate passed another resolution that called again for total divestment. ${ }^{91}$ Later that month, President Swain and the Board of Trustees decided to reconsider arguments in support of divestment from student anti-apartheid leaders. ${ }^{92}$ Kemper, who had succeeded Jemley as SGA president, met with trustees on September 23 to once again discuss divestment. Kemper recommended that an ad hoc committee of four board members be composed to study the Student Senate’s Divestment Resolution and report back to the Board of Trustees in October to establish a "detailed policy position” on divestment. After a lengthy discussion, the Board of Trustees passed the motion. ${ }^{93}$ All that was left for Kemper and the Coalition for Total Divestment was to await the Foundation’s report and a definitive decision from the Board of Trustees.

A month later, on October 28, the Board of Trustees reconvened one final time to vote on the divestment issue. Harry Jones, the then Chairman of the Board of Directors of the University of Louisville Foundation, detailed the committee’s report to members of the Board of Trustees. He stated that since April 23 the Foundation had "aggressively implemented a South African divestment policy” and instructed the university not to invest in 192 of the 286 US companies that did business in South Africa. ${ }^{94}$ However, Jones took this even further by recognizing the “intense emotions" the issue had evoked in the university community and recommended to the 
Board of Trustees that they "immediately" adopt a policy of total divestment, with the promise of complete withdrawal of university funds from South Africa no later than November 1, $1987 .{ }^{95}$ The board then voted to accept this proposal, making the University of Louisville the first large university in the state of Kentucky to totally divest from South Africa. ${ }^{96}$ After months of meetings, demonstrations, petitions, and protests, anti-apartheid activists at the University of Louisville had finally achieved their goal of securing total divestment. The 1985 divestment campaign at the University of Louisville had provided the necessary force to push university administrators to take a stand against the inherent injustice and inequality of apartheid.

\section{$\underline{\text { Conclusion }}$}

With the board's decision, the University of Louisville became the first major institution in the state of Kentucky to pursue total divestment from South Africa. ${ }^{97}$ Not only that, but the university also staked its claim as the only major public university in the American South to divest completely from South Africa. ${ }^{98}$ Most schools that had called for divestment were private institutions situated near urban centers on either coast, such as Columbia, Harvard, and Stanford. While similar movements occurred on the campuses of Duke University and Georgia State, neither movement secured total divestment by the time administrators at the University of Louisville had made their decision. The unique character of the University of Louisville as a public institution from the South made the divestment campaign one-of-a-kind in the grander nationwide divestment movement, and gives the University of Louisville students a distinct place within the American anti-apartheid movement.

The divestment campaign also stands out within the larger legacy of student activism at 
the University of Louisville. The university has a long history of peaceful activism, stemming all the way back to protests against racial discrimination and the Vietnam War in the 1960s. ${ }^{99}$ University of Louisville students routinely resorted to peaceful demonstration to address specific grievances. In 1969, Blaine Hudson and a group of students were arrested and expelled for occupying the office of the Dean of Arts and Sciences as a way of drawing attention to the lack of minority teachers at the university (Though Hudson would be expelled for these action, ironically he went onto to become the University of Louisville's Dean of Arts and Sciences in 2004). ${ }^{100}$ Students also staged demonstrations against high prices for books at the campus bookstore, protested for increased hours at the library, and lobbied for extended curfews for female students. ${ }^{101}$ The students involved in the 1985 divestment campaign were following in the footsteps of student activists before them, yet at the time they were unaware of the significance of their movement. The 1985 divestment campaign ended up being one of the last major demonstrations for social justice at the University of Louisville. This fact alone gives the divestment campaign a distinct place within the long tradition of student activism at the university.

By the fall of 1985, divestment protests had occurred at 20 or more American universities. ${ }^{102}$ Though most university administrations were generally hesitant or resistant to divest initially, the efforts on the part of the students would not be in vain. By early 1986, 40 of the top 100 American universities (by size of endowment) had chosen to at least partially divest from South Africa, with another 7 having elected for total divestment. ${ }^{103}$ By 1989, that number of universities that had adopted total divestment rose to $19 .{ }^{104}$ Before long, local governments, major municipalities, and private firms were joining in the divestment movement. While overall, university divestment did not directly cripple the economy of South Africa, the campaign was 
essential in generating popular mobilization in the United States for the development of antiapartheid economic sanctions. ${ }^{105}$ Overall, anti-apartheid divestment campaigns placed the American people at the helm of the international anti-apartheid movement. This sentiment led members of Congress to introduce legislation detailing economic sanctions against South Africa in 1986.

Soon after the 1985 university divestment campaigns, a group of like-minded Congressmen began coordinating to pass economic sanctions aimed at apartheid. Led by California Representative Ron Dellums, a bipartisan coalition approved the Comprehensive Anti-Apartheid Act in 1986. The Dellums Bill, as it came to be known, was aimed at prohibiting American companies and institutions from “doing business as usual” with the apartheid regime. ${ }^{106}$ The proposed bill forced American oil companies to relinquish investments in South Africa, required all American companies to divest within 180 days, and imposed an import ban on all South African goods other than "strategic minerals". ${ }^{107}$ Despite being vetoed by President Reagan, the bill made it through both the House and the Senate and overrode the president's decision. The bill came into effect in October 1986, officially imposing economic sanctions that ultimately led to the dissolution of apartheid rule in South Africa. The Dellums Bill was essentially a death certificate to the apartheid government in South Africa, as the economic repercussions proved to be catastrophic.

The economic sanctions placed on the South African government proved to a fatal blow to the racist regime. Financially, the country suffered as more and more companies and investors pulled capital out of the country. However, the predominant effect sanctions had on the white South African government was psychological. Gone was the comfort in knowing that the world's preeminent superpower was in their corner. The exodus of American companies from South 
Africa combined with the threat of further sanctions was a compelling factor in forcing the leaders of the Nationalist Party to the negotiating table. The cost of maintaining minority rule over the black majority had gotten too high. By the late 1980s, Nationalist Party leaders had begun to engage in talks with black leaders on the topic of governmental transition. By 1991, most formal legislation of apartheid had been abolished, and in 1994 a new coalition government led by Mandela had taken the helm of the nation. Economic sanctions against South Africa had proven to be successful in achieving their stated goal: the dismantling of apartheid and the introduction of a new, equal government in South Africa.

The effect that the divestment campaign had on apartheid's defeat cannot be understated. Charlene Smith, long time political journalist, anti-apartheid activist and authorized biographer of Mandela, remarked in an interview that the student divestment movements "saved (the) lives" of black, Indians, and Coloured populations across South Africa. Though students were not personally familiar with the people of South Africa, they were willing to take a stand in front of their parents, university administrators, and their fellow students simply because, as Smith noted, "they believed in a greater good." 108 The outbreak of divestment movements across American university campuses in 1985 galvanized support for the anti-apartheid movement and indirectly led to the development of economic sanctions against apartheid South Africa. As a whole, the university divestment movement was a key factor in the dismantling of apartheid at the end of the twentieth century, and it must be viewed as a significant crusade within the context of the the global anti-apartheid movement.

The legacy of the 1985 divestment campaign at the University of Louisville lasts to this day. It proved not only to be the driving force in compelling the institution to become the first public university in the South to fully divest from apartheid South Africa, but also remains one 
of the last significant instances of student activism at the University of Louisville. The students showed that a movement can have a drastic effect on university policy. However, they also proved that the "excellence to which this university aspires must also be earned." 109 If the University of Louisville wishes to count itself amongst other leading American institutions, then it is up to the students, the faculty, and the administration alike to hold ourselves to a higher standard. We must all continue to maintain our moral obligation to proliferate knowledge, tolerance, and respect of all peoples. In 1985, a group of students dedicated themselves to this ideal, upholding their responsibilities to fight for equality and justice, despite the obstacles. It is the hope of the author that this thesis, while providing a historical analysis of apartheid and the divestment movement, will motivate readers to always hold themselves, their peers, and their superiors to the same moral standard that student activists did in 1985. The divestment campaign remains, to this day, one of the most significant instances of student activism in history, and shows how anyone can spark change even from an ocean away.

\footnotetext{
${ }^{1}$ Nessen, Joshua. "Anti-Apartheid Protests Sweep Campuses Across the Country." Student-Anti Apartheid Newsletter, May 1985.

${ }^{2}$ Worden, Nigel. The Making of Modern South Africa. Fifth ed. N.p.: Blackwell, n.d. Print, 104.

${ }^{3}$ Worden, The Making of Modern South Africa, 104.

${ }^{4}$ Ibid., 104.

${ }^{5}$ Ibid., 105.

${ }^{6}$ Mandela, Nelson. Long Walk to Freedom: The Autobiography of Nelson Mandela. Boston: Little, Brown, 1994. Print, 167.

${ }^{7}$ Worden, The Making of Modern South Africa, 105.

${ }^{8}$ Mandela, Long Walk to Freedom, 132.

${ }^{9}$ Worden, The Making of Modern South Africa, 109.

${ }^{10}$ Mandela, Long Walk to Freedom, 133.

${ }^{11}$ Ibid., 140.

${ }^{12}$ Worden, The Making of Modern South Africa, 106.

13 Mandela, Long Walk to Freedom, 259.
} 
${ }^{14}$ Worden, The Making of Modern South Africa, 116.

15 Ibid., 116

${ }^{16}$ Mandela, Long Walk to Freedom, 166.

17 Ibid., 239.

18 Security Council Resolution 134, Question Relating to the Situation in the Union of South Africa, 1 April, 1960.

${ }^{19}$ Mandela, Long Walk to Freedom, 238.

${ }^{20}$ Ibid., 166.

${ }^{21}$ Ibid., 387.

${ }^{22}$ Worden, The Making of Modern South Africa, 128.

${ }^{23}$ Mandela, Long Walk to Freedom, 238.

${ }^{24}$ Worden, The Making of Modern South Africa, 129.

${ }^{25}$ Borstelmann, Thomas. Apartheid's Reluctant Uncle: The United States and Southern Africa in the Early Cold War. New York: Oxford UP, 1993. Print, 149.

26 “Hector Pieterson's body carried alongside his sister Antoinette”. Digital image. Mirror Online. Accessed October 12, 2015. Mirror.co.uk.

27 Smith, Gaddis. Morality, Reason, and Power: American Diplomacy in the Carter Years. New York: Hill and Wang, 1986. Print, 6.

${ }^{28}$ Smith, Morality, Reason, and Power, 134.

${ }^{29}$ Ibid., 133.

${ }^{30}$ Ibid., 135.

${ }^{31}$ Ibid., 134.

32 Roth, Molly. "Encyclopedia of Greater Philadelphia." Sullivan Principles. 2013. Accessed March 16, 2016. http://philadelphiaencyclopedia.org/archive/sullivan-principles/.

33 Borstelmann, Thomas. The Cold War and the Color Line: American Race Relations in the Global Arena. Cambridge, MA: Harvard UP, 2001. Print, 255.

34 Smith, Morality, Reason, and Power, 156.

35 Nesbitt, Francis Njubi. Race for Sanctions: African Americans Against Apartheid, 19461994. Bloomington: Indiana UP, 2004. Print, 113.

${ }^{36}$ Massie, Loosing the Bonds, 486.

${ }^{37}$ Nesbitt, Race for Sanctions, 114.

${ }^{38}$ Massie, Loosing the Bonds, 558.

39 Ibid., 559.

${ }^{40}$ Nesbitt, Race for Sanctions, 123.

${ }^{41}$ Ibid., 125.

${ }^{42}$ Massie, Loosing the Bonds, 559.

43 Nesbitt, Race for Sanctions, 123.

44 Janet Zakutansky to the Board of Trustees, March 25, 1985, University of Louisville Archives and Special Collections, Louisville, KY.

${ }^{45}$ Worden, The Making of Modern South Africa, 131.

${ }^{46}$ Massie, Loosing the Bonds, 568.

${ }^{47}$ Massie, Loosing the Bonds, 568.

${ }^{48}$ Ibid., 569.

49 National Divestment Protest Day. Columbia Coalition for a Free South Africa, 1985.

${ }^{50}$ Massie, Loosing the Bonds, 569.

${ }^{51}$ National Divestment Protest Day. Columbia Coalition for a Free South Africa, 1985. 
${ }^{52}$ Massie, Loosing the Bonds, 569.

${ }^{53}$ Ibid., 569.

54 “Mandela Hall”, George Cohen. Digital image. African Activist Archive. Accessed December 14, 2015.

${ }^{55}$ Massie, Loosing the Bonds, 569.

${ }^{56}$ The Divestment Blockade. Columbia, NY: Columbia Coalition for a Free South Africa, 1985.

${ }^{57}$ Murphy, Jacqueline Shea. "Divest is Life or Death Issue." Columbia Spectator 4 April 1985: n. pag. Print.

${ }_{58}^{58}$ Massie, Loosing the Bonds, 570.

${ }^{59}$ Ibid., 571.

${ }^{60}$ Ibid., 571.

${ }^{61}$ National Divestment Protest Day. Columbia Coalition for a Free South Africa.

${ }^{62}$ Larry Rohter, “Anti-South Africa rallies indicate resurgence of U.S. student activism.” The New York Times 25 April 1985

${ }^{63}$ Nesbitt, Race for Sanctions, 137.

${ }^{64}$ Coleman, Yvonne D. "'UofL Rally against Apartheid"' Louisville Defender 25 Apr. 1985: n. pag. Print.

${ }^{65}$ University of Louisville, Student Senate, A Resolution on Divestment from the Republic of South Africa, 19 Feb. 1985

${ }^{66}$ Coleman, Yvonne D. "'UofL Rally against Apartheid"' Louisville Defender 25 Apr. 1985: n. pag. Print.

${ }^{67}$ Coleman, Yvonne D. "'UofL Rally against Apartheid"' Louisville Defender 25 Apr. 1985: n. pag. Print.

${ }^{68}$ Coleman, Yvonne D. "'UofL Rally against Apartheid"' Louisville Defender 25 Apr. 1985: n. pag. Print.

${ }^{69}$ Frank Jemley to the Trustees, March 25, 1985, Board of Trustees Minutes, University of Louisville Archives and Special Collections, Louisville, KY.

${ }^{70}$ Jemley to the Trustees, March 25, 1985, Board of Trustees Minutes, University of Louisville Archives and Special Collections, Louisville, KY.

${ }^{71}$ Donald Swain to the Trustees, March 25, 1985, Board of Trustees Minutes, University of Louisville Archives and Special Collections, Louisville, KY.

${ }^{72}$ Donald Swain to the Trustees, March 25, 1985, Board of Trustees Minutes, University of Louisville Archives and Special Collections, Louisville, KY.

${ }^{73}$ Vicki Alexander to the Trustees, March 25, 1985, Board of Trustees Minutes, University of Louisville Archives and Special Collections, Louisville, KY.

${ }^{74}$ Janet Zakutansky to the Trustees, March 25, 1985, Board of Trustees Minutes, University of Louisville Archives and Special Collections, Louisville, KY.

75 Jemley to the Trustees, March 25, 1985, Board of Trustees Minutes, University of Louisville Archives and Special Collections, Louisville, KY.

${ }^{76}$ Porter to the Trustees, March 25, 1985, Board of Trustees Minutes, University of Louisville Archives and Special Collections, Louisville, KY.

${ }^{77}$ Porter to the Trustees, March 25, 1985, Board of Trustees Minutes, University of Louisville Archives and Special Collections, Louisville, KY.

${ }^{78}$ Blume to the Trustees, March 25, 1985, Board of Trustees Minutes, University of Louisville Archives and Special Collections, Louisville, KY.

${ }^{79}$ Minutes of the Board of Trustees, March 25, 1985, University of Louisville Archives and 
Special Collections, Louisville, KY

${ }^{80}$ Baye, Betty Winston "UofL Students, others protest business ties with South Africa” The Courier-Journal 24 Apr. 1985: n. pag. Print.

${ }^{81}$ Baye, Betty Winston "UofL Students, others protest business ties with South Africa” The Courier-Journal 24 Apr. 1985: n. pag. Print.

82 “The Thinker - Holding a Sign Calling for the University to Divest”. Digital Image.

University of Louisville Archives and Special Collections. Accessed September 23, 2016. Louisville.edu.

${ }^{83}$ Stanley, T.L. "Students call for divestiture locally and nationally” The Louisville Cardinal 25 Apr. 1985: n. pag. Print.

${ }^{84}$ Rutherford, Glenn “Occupation of building at UofL ends” The Courier-Journal 25 Apr. 1985: n. pag. Print.

${ }^{85}$ Rutherford, Glenn “Occupation of building at UofL ends” The Courier-Journal 25 Apr. 1985: n. pag. Print.

${ }^{86}$ Cross, Al "UofL Foundation votes to sell some stock linked to South Africa” The CourierJournal 24 Apr. 1985: n. pag. Print.

${ }^{87}$ Cross, Al "UofL Foundation votes to sell some stock linked to South Africa” The CourierJournal 24 Apr. 1985.

${ }^{88}$ Stanley, T.L. "Students call for divestiture locally and nationally" The Louisville Cardinal 25 Apr. 1985: n. pag. Print.

${ }^{89}$ Stanley, T.L. "Students call for divestiture locally and nationally" The Louisville Cardinal 25 Apr. 1985: n. pag. Print.

90 Stanley, T.L. "Students call for divestiture locally and nationally" The Louisville Cardinal 25 Apr. 1985: n. pag. Print.

${ }^{91}$ Pack, T.A. “SGA demands new divestment” The Louisville Cardinal 5 Sep. 1985: n. pag. Print.

92 Stanley, T.L. “Trustees hear divestment arguments” The Louisville Cardinal 26 Sep. 1985: n. pag. Print.

93 Minutes of the Board of Trustees, September 23, 1985, University of Louisville Archives and Special Collections, Louisville, KY.

${ }^{94}$ Harry Jones to the Board of Trustees, October 28, 1985, Board of the Trustees Minutes, University of Louisville Archives and Special Collections, Louisville, KY

95 Jones to the Board of Trustees, October 28, 1985, University of Louisville Archives and Special Collections, Louisville, KY

${ }^{96}$ Minutes of the Board of Trustees, October 28, 1985, University of Louisville Archives and Special Collections, Louisville, KY.

97 Stanley, T.L. “Trustees vote to divest \$6.5 million in two years” The Louisville Cardinal 31 Oct. 1985: n. pag. Print.

${ }^{98}$ Cross, Al "UofL to divest itself of all stock related to S. Africa within 2 years" The CourierJournal 29 Oct. 1985: n. pag. Print.

${ }^{99}$ Cox, Dwayne, and William James Morison. The University of Louisville. Lexington, KY: U of Kentucky, 2000. Print, 147.

${ }^{100}$ Cox, Morison, The University of Louisville, 146.

101 Ibid., 151.

${ }^{102}$ Crawford, Neta, and Audie Klotz. How Sanctions Work: Lessons from South Africa. New York: St. Martin's, 1999. Print, 134. 
${ }^{103}$ Crawford, Klotz, How Sanctions Work: Lessons from South Africa, 135.

${ }^{104}$ Crawford, Klotz, How Sanctions Work: Lessons from South Africa, 135.

${ }^{105}$ Crawford, Klotz, How Sanctions Work: Lessons from South Africa, 135-8.

106 Nesbitt, Race for Sanctions, 139.

107 Ibid., 150-1.

108 Smith, Charlene. Telephone interview. 1 Feb. 2016.

109 Jemley to the Board of Trustees, March 25, 1985, University of Louisville Archives and Special Collections, Louisville, KY. 


\section{Bibliography}

American Committee on Africa, "Student Anti-Apartheid Newsle

Baye, Betty Winston "UofL Students, others protest business ties with South Africa” The Courier-Journal 24 Apr. 1985: n. pag. Print.

Borstelmann, Thomas. Apartheid's Reluctant Uncle: The United States and Southern Africa in the Early Cold War. New York: Oxford UP, 1993. Print.

Borstelmann, Thomas. The Cold War and the Color Line: American Race Relations in the Global Arena. Cambridge, MA: Harvard UP, 2001. Print.

Coleman, Yvonne D. "'UofL Rally against Apartheid"' Louisville Defender 25 Apr. 1985: n. pag. Print.

Crawford, Neta, and Audie Klotz. How Sanctions Work: Lessons from South Africa. New York: St. Martin's, 1999. Print.

Cross, Al "UofL Foundation votes to sell some stock linked to South Africa" The CourierJournal 24 Apr. 1985 n. pag. Print.

Cross, Al "UofL to divest itself of all stock related to S. Africa within 2 years" The CourierJournal 29 Oct. 1985: n. pag. Print.

Cox, Dwayne, and William James Morison. The University of Louisville. Lexington, KY: U of Kentucky, 2000. Print.

Dranikoff, Lee, Tim Koller, and Antoon Schneider. "Divestiture - Strategy's Missing Link." The Harvard Business Review, May 2002. Accessed March 11, 2016.

“Hector Pieterson’s body carried alongside his sister Antoinette”. Digital image. Mirror Online. Accessed October 12, 2015. Mirror.co.uk.

"Mandela Hall”, George Cohen. Digital image. African Activist Archive. Accessed December 14, 2015.

Mandela, Nelson. Inauguration as President of the Democratic Republic of South Africa. Pretoria. 10 May 1994. Web.

Mandela, Nelson. Long Walk to Freedom: The Autobiography of Nelson Mandela. Boston: Little, Brown, 1994. Print.

Massie, Robert. Loosing the Bonds: The United States and South Africa in the Apartheid Years. New York: Nan A. Talese/Doubleday, 1997. Print.

Minutes of the Board of Trustees. University of Louisville Archives and Special Collections, Louisville, Kentucky. 1985.

Murphy, Jacqueline Shea. "Divest Is Life or Death Issue." Columbia Spectator 4 Apr. 1985: n. pag. Print.

National Divestment Protest Day. Columbia, NY: Columbia Coalition for a Free South Africa, 1985. Print.

Nesbitt, Francis Njubi. Race for Sanctions: African Americans Against Apartheid, 1946-1994. Bloomington: Indiana UP, 2004. Print.

Nessen, Joshua. "Anti-Apartheid Protests Sweep Campuses Across the Country." Student-Anti Apartheid Newsletter, May 1985.

Pack, T.A. “SGA demands new divestment” The Louisville Cardinal 5 Sep. 1985: n. pag. Print.

Roth, Molly. "Encyclopedia of Greater Philadelphia." Sullivan Principles. 2013. Accessed March 16, 2016. http://philadelphiaencyclopedia.org/archive/sullivan-principles/.

Rutherford, Glenn “Occupation of building at UofL ends” The Courier-Journal 25 Apr. 1985:

n. pag. Print. 
Security Council Resolution 134, Question Relating to the Situation in the Union of South Africa, 1 April, 1960.

Smith, Charlene. Telephone interview. 1 Feb. 2016.

Smith, Gaddis. Morality, Reason, and Power: American Diplomacy in the Carter Years. New York: Hill and Wang, 1986. Print.

Starks, Robert, Professor. Free South Africa! Chicago, IL: Free South Africa Movement, 1984. Print.

Stanley, T.L. "Students call for divestiture locally and nationally” The Louisville Cardinal 25 Apr. 1985: n. pag. Print.

Stanley, T.L. "Trustees hear divestment arguments” The Louisville Cardinal 26 Sep. 1985: n. pag. Print.

Stanley, T.L. “Trustees vote to divest \$6.5 million in two years” The Louisville Cardinal 31 Oct. 1985: n. pag. Print.

The Divestment Blockade. Columbia, NY: Columbia Coalition for a Free South Africa, 1985. Print.

“The Thinker - Holding a Sign Calling for the University to Divest”. Digital Image. University of Louisville Archives and Special Collections. Accessed September 23, 2016. Louisville.edu.

University of Louisville, Student Senate, A Resolution on Divestment from the Republic of South Africa, 19 Feb. 1985

Worden, Nigel. The Making of Modern South Africa. Fifth ed. N.p.: Blackwell, n.d. Print.

Worger, William H. Africa and the West. Ed. Nancy L. Clark and Edward A. Alpers. Oxford: Oxford UP, 2010. Print. 